\title{
Italian multicenter study on infection hazards during dental practice: Control of environmental microbial contamination in public dental surgeries
}

Paolo Castiglia ${ }^{1}$, Giorgio Liguori ${ }^{2}$, Maria Teresa Montagna*3, Christian Napoli ${ }^{3}$, Cesira Pasquarella ${ }^{4}$, Margherita Bergomi ${ }^{5}$, Leila Fabiani6, Silvano Monarca ${ }^{7}$, Stefano Petti ${ }^{8}$ and SItI Working Group Hygiene in Dentistry

Address: ${ }^{1}$ Istituto di Igiene e Medicina Preventiva, Università degli Studi di Sassari, Via P. Manzella 4, 07100 Sassari, Italy, ${ }^{2}$ Cattedra di Igiene ed Epidemiologia, Università degli Studi di Napoli "Parthenope", Via F. Acton, 38 - 80133 Napoli, Italy, ${ }^{3}$ Dip. di Scienze Biomediche ed Oncologia Umana - Sez. Igiene, Università degli Studi di Bari, Piazza G. Cesare 11, 70124 Bari, Italy, ${ }^{4}$ Dip di Sanità Pubblica, Università degli Studi di Parma, Via Volturno 39, 43100 Parma, Italy, 5Dip. di Scienze di Sanità Pubblica, Università di Modena e Reggio Emilia, Via Campi 287 - 41100 Modena, Italy, ${ }^{6}$ Dip. Di Medicina Interna e Sanità Pubblica - Cattedra di Igiene, Università degli Studi di L'Aquila, Via Vetoio 67010 Coppito di L'Aquila, L'Aquila, Italy, ${ }^{7}$ Dip. di Specialità Medico Chirurgiche e Sanita' Pubblica, Università degli Studi di Perugia, via Del Giochetto, 06100 Perugia, Italy and ${ }^{8}$ Dip. Scienze di Sanità Pubblica "G. Sanarelli", Università di Roma "La sapienza", Piazzale Aldo Moro 5, 00185 Roma, Italy

Email: Paolo Castiglia - paolo.castiglia@uniss.it; Giorgio Liguori - giorgio.liguori@uniparthenope.it;

Maria Teresa Montagna* - montagna@igiene.uniba.it; Christian Napoli - c.napoli@igiene.uniba.it;

Cesira Pasquarella - ira.pasquarella@unipr.it; Margherita Bergomi -m.bergomi@unimo.it; Leila Fabiani - leila.fabiani@cc.univaq.it;

Silvano Monarca - monarca@unipg.it; Stefano Petti - stefano.petti@uniroma1.it; SItI Working Group Hygiene in

Dentistry - montagna@igiene.uniba.it

* Corresponding author

Published: 29 May 2008

BMC Public Health 2008, 8:187 doi:10.1 I86/147|-2458-8-187
Received: 30 July 2007

Accepted: 29 May 2008

This article is available from: http://www.biomedcentral.com/I47I-2458/8//87

(c) 2008 Castiglia et al; licensee BioMed Central Ltd.

This is an Open Access article distributed under the terms of the Creative Commons Attribution License (http://creativecommons.org/licenses/by/2.0), which permits unrestricted use, distribution, and reproduction in any medium, provided the original work is properly cited.

\begin{abstract}
Background: The present study assessed microbial contamination in Italian dental surgeries.

Methods: An evaluation of water, air and surface microbial contamination in 102 dental units was carried out in eight Italian cities.

Results: The findings showed water microbial contamination in all the dental surgeries; the proportion of water samples with microbial levels above those recommended decreased during working. With regard to Legionella spp., the proportion of positive samples was 33.3\%. During work activity, the index of microbial air contamination (IMA) increased. The level of microbial accumulation on examined surfaces did not change over time.
\end{abstract}

Conclusion: These findings confirm that some Italian dental surgeries show high biocontamination, as in other European Countries, which highlights the risk of occupational exposure and the need to apply effective measures to reduce microbial loads. 


\section{Background}

Infection hazards linked to dental practice are not a recent problem. Through this kind of health care practice, many infectious agents, both viruses (Hepatitis B virus, Hepatitis C virus, Human Immunodeficency virus, Herpes Simplex virus, Epstein Barr virus and Cytomegalovirus) and bacteria (Streptococcus pneumoniae, Mycobacterium tuberculosis, Klebsiella pneumoniae, Escherichia coli, Legionella pneumophila and Pseudomonas aeruginosa), may be transmitted. Some studies have shown that the environment (water, air and surfaces) can play an important role in this context: water stagnation, biofilm production and lack of disinfection in dental unit water systems (DUWS) promote the proliferation of microorganisms [1-4]. In addition, ablators, turbines and air-water syringes may nebulize the saliva and microorganisms contained in the patient's mouth, with the consequent contamination of the surrounding air and surfaces [5]. This suggests a potential risk of infection, especially from water, particularly in patients who are immunocompromised due to drug therapy, alcohol abuse, systemic diseases, and old age [6]. Some authors have declared that there is no evidence that dental unit water is harmful to patients, even though the lower the water contamination, the lower the risk to patients, and exposure to water that contains high numbers of bacteria violates basic principles of clinical infection control $[7,8]$. Moreover, there may be an occupational hazard because of much greater exposure of the staff [9-16]. Therefore, in order to minimize the hazards linked to dental practice, various cut-offs of total viable count (TVC) in dental unit water have been proposed. In 1995, the American Dental Association (ADA) stated that the TVC must be $\leq 200 \mathrm{CFU} / \mathrm{mL}$ (Colony Forming Unit), which was based on the quality assurance standard established for dialysate fluid [17]. The Centers for Diseases Control and Prevention (CDC) in their 2003 guidelines, reported that, for coolant water used in non-surgical dental procedures, the TVC must be $\leq 500 \mathrm{CFU} / \mathrm{mL}$, as established by the US Environmental Protection Agency for drinking water and the ADA in $2007[8,18]$.

A multicenter study that assessed the microbiology of DUWSs in general dental practice across seven European countries has shown that a substantial proportion have high levels of microbial contamination, which highlights the risk of occupational exposure and cross-infection during dental practice [19].

Italy did not participate in that study and no national data on this phenomenon have been reported; in particular, only a few papers on environmental microbial contamination in dental surgeries and cross-infection risk are present in literature $[20,21]$. Moreover, different methods were used in these studies.
The aim of this study was to evaluate the infection hazards linked to dental practice by checking the microbial contamination of water, air and surfaces in public dental surgeries in eight Italian cities.

\section{Methods}

The study was carried out in 102 dental units (87 university and 15 public district facilities) at 64 dental clinics in eight Italian cities. Participation in the study was on a voluntary basis. All the participants collected specimens during the spring on the same Monday. Water specimens were collected from dental units (cup fillers and/or airwater syringes) at the start and end of morning practice (generally 08:00 and 13:00 h). Air and surfaces were sampled before the start $\left(\mathrm{T}_{0}\right.$, empty room) and during clinical practice $\left(\mathrm{T}_{1}\right.$, when the dentist, assistant and patient were present). In addition, on the same day, 91 water samples were collected from the washbasin taps at 08:00 h.

\section{Evaluation of water microbial contamination}

All analyses were performed in conformity with Italian law [22], which complies with the European Council Directive 98/83/EC of 3 November 1998 [23]. The following parameters were determined:

- TVC after 7 days of incubation at $22^{\circ} \mathrm{C}$ and 5 days at $36^{\circ} \mathrm{C}$ using Yeast Extract Agar; in order to calculate the percentage exceeding safety levels, a threshold value of 20 $\mathrm{CFU} / \mathrm{mL}$ at $36^{\circ} \mathrm{C}$ and $100 \mathrm{CFU} / \mathrm{mL}$ at $22^{\circ} \mathrm{C}$ was considered, in accordance with Italian law [22]; moreover, a threshold value of $500 \mathrm{CFU} / \mathrm{mL}$ was considered, as indicated by the CDC in 2003 [8];

- total coliforms presence after $24 \mathrm{~h}$ at $37^{\circ} \mathrm{C}$ and E. coli presence after $24 \mathrm{~h}$ at $44^{\circ} \mathrm{C}$ were determined by filtering twice $100 \mathrm{~mL}$ water through $0.45 \mu \mathrm{m}$ membranes and using TTC Tergitol 7 agar medium; absence of both parameters in $100 \mathrm{~mL}$ was required [22].

In addition, the 87 university dental units were tested for $P$. aeruginosa and Legionella spp. Specimens were collected by mixing together equal volume of water from all water points of each dental unit (ablators, high- and low-speed handpieces, air-water syringes and cap fillers).

The presence of $P$. aeruginosa was detected by filtering 250 $\mathrm{mL}$ water through $0.45-\mu \mathrm{m}$ membranes; these were then seeded on CN Pseudomonas agar and incubated at $37^{\circ} \mathrm{C}$ for $48 \mathrm{~h}$. Absence of bacteria in $250 \mathrm{~mL}$ samples was required [22].

The presence of Legionella spp. was detected by filtering $1 \mathrm{~L}$ water through $0.2-\mu \mathrm{m}$ isopore polycarbonate membranes; these were then resuspended in $10 \mathrm{~mL}$ of the same water sample and vortexed. Five $\mathrm{mL}$ was treated at $50^{\circ} \mathrm{C}$ for 30 
min and seeded $(0.1 \mathrm{~mL})$ on cicloeximide, glicine, polymyxin, vancomycin (GVPC) agar medium. The remaining $5 \mathrm{~mL}$ was cold-seeded using the same technique. After incubation at $36^{\circ} \mathrm{C}$ for $8-10$ days in a damp environment at $2.5 \% \mathrm{CO}_{2}$, quantitative assessment was made, and expressed as CFU/L. Suspect colonies were subcultured on charcoal yeast extract (CYE) agar and buffered charcoal yeast extract (BCYE) agar and those ascribable to the Legionella genus were serologically identified [24].

All samples were collected in sterile bottles and immediately transported in a cool box $\left(4-8^{\circ} \mathrm{C}\right)$ to the laboratory.

\section{Evaluation of microbial air contamination}

Microbial air contamination was assessed by active sampling using the Surface Air System (SAS) to determine the number of CFU per $\mathrm{m}^{3}$, and by passive sampling using settle plates, $9 \mathrm{~cm}$ in diameter, exposed for $1 \mathrm{~h}$, to determine the index of microbial air contamination (IMA) [25]. During the sampling, windows and doors were kept closed. The TVC was determined on Plate Count Agar.

The SAS was used to collect $180 \mathrm{~L}$ air in $1 \mathrm{~min}$, near the dental unit, at $130-150 \mathrm{~cm}$ above the floor; after which plates were incubated for $48 \mathrm{~h}$ at $36^{\circ} \mathrm{C}$, and the number of CFU was adjusted using the conversion table provided by the SAS producer and reported for $1 \mathrm{~m}^{3}$ of air. The threshold value was assessed at $180 \mathrm{CFU} / \mathrm{m}^{3}$, as recommended for conventionally ventilated environments [26].

To determine the IMA, expressed as CFU/plate/h after 48 $\mathrm{h}$ at $36^{\circ} \mathrm{C}$ incubation, Petri dishes (diameter $9 \mathrm{~cm}$ ) containing solid nutrient medium were left open to the air for $1 \mathrm{~h}$ at $1 \mathrm{~m}$ above floor level and at least $1 \mathrm{~m}$ from any relevant obstacle. A threshold of 25 was considered adequate $[25,27]$.

Overall, 78 air samples were collected (46 using SAS and 32 using settle plates). As a rule, the air sampling was performed in the middle of each surgery, in a position near the head of the patient. When two or more samples were taken as results of surgery size, the mean value was used.

\section{Evaluation of surface microbial contamination}

Microbiological analysis of the surfaces was performed using membrane filters (Sartorius SM 13806 AC, $\varnothing 47$ $\mathrm{mm}, 17.34 \mathrm{~cm}^{2}, 0.45-\mu \mathrm{m}$ pores) to determine microbial accumulation (MA) [28]. In order to calculate TVC, one sterile membrane was pressed with digital pressure for 30 $\mathrm{s}$, using sterile gloves, on each surface to be controlled. The membrane was directly collected using sterile tweezers and placed on a sterile, dehydrated culture media previously moistened with $3 \mathrm{~mL}$ sterile distilled water. A total of 111 samples from the countertops and 110 from switches were collected. The results for MA were expressed as $\mathrm{CFU} / \mathrm{cm}^{2}$ after $48 \mathrm{~h}$ incubation at $36^{\circ} \mathrm{C}$; a value of 1 $\mathrm{CFU} / \mathrm{cm}^{2}$ was considered acceptable [27].

\section{Statistical analysis}

As regard dental units contamination, the statistical analysis of data was "machine oriented", i.e. no clustering analysis has been performed in case of more then one unit for dental surgery. Due to the skewed distribution of data, a logarithmic transformation was applied. Differences between transformed means of $\mathrm{T}_{0}$ and $\mathrm{T}_{1}$ counts were evaluated using Student's $t$ test for paired comparisons. If a threshold was reached, prevalence was calculated as the proportion of values exceeding the cut-off. Independence between categorical variables was tested using Fisher's exact test. The McNemar test was applied for paired comparisons. The possible interference between the presence of $P$. aeruginosa and Legionella spp. was tested via Fisher's exact test. $\mathrm{p}<0.05$ was considered statistically significant.

\section{Results}

TVCs at 22 and $36^{\circ} \mathrm{C}$ from water samples are shown in Table $1 . \mathrm{T}_{0}$-logarithmic means were higher than $\mathrm{T}_{1}$ at 22 and $36^{\circ} \mathrm{C}$ for cup fillers ( 1.6 vs $1.3, \mathrm{p}=0.16$ and 1.7 vs $1.2, \mathrm{p}=0.02)$ and for air-water syringes $(1.8$ vs $1.4, \mathrm{p}=$ 0.03 and 1.7 vs $1.2, \mathrm{p}=0.01$ ). At the same time, the proportion of samples with higher levels than those recommended by Italian law was higher at $\mathrm{T}_{0}$ than at $\mathrm{T}_{1}$ at 22 and $36^{\circ} \mathrm{C}$. In fact, these proportions decreased significantly at $\mathrm{T}_{1}$ for all parameters (McNemar test: $\mathrm{p}<0.05$ ), except for cup-fillers at $22^{\circ} \mathrm{C}$, for which the reduction was not significant (McNemar test: $\mathrm{p}=0.19$ ). No samples exceeded the CDC 2003 threshold value of $500 \mathrm{CFU} / \mathrm{mL}$ (data not shown).

The TVCs from tap water were lower than those from dental units at $\mathrm{T}_{0}(\mathrm{p}<0.001$, data not shown). Total and fecal coliforms were not found.

Table 2 shows the relationship between Legionella spp. and $P$. aeruginosa isolated from 87 DUWSs. The prevalence of $P$. aeruginosa was $13.8 \%$, while the prevalence of Legionella spp. was $33.3 \%$. Only one sample $(1.1 \%)$ was positive both for $P$. aeruginosa and Legionella spp., while $47(54.0 \%)$ were negative for both microorganisms (onetailed Fisher's exact test, $\mathrm{p}=0.04$ ) (Table 2).

As regards air contamination, IMA was almost four times higher at $\mathrm{T}_{1}$ than at $\mathrm{T}_{0}$ (Table 3 ), with statistically significant differences between the two sampling times $(\mathrm{p}<$ $0.0001)$. Instead, the level of air contamination assessed by SAS did not change between $\mathrm{T}_{0}$ and $\mathrm{T}_{1}$ (from 104.7 $\mathrm{CFU} / \mathrm{m}^{3}$ mean value at $\mathrm{T}_{0}$ to $107.2 \mathrm{CFU} / \mathrm{m}^{3}$ at $\mathrm{T}_{1}, \mathrm{p}=0.39$ ) (Table 4). The level of microbial accumulation on the countertops and switches of the dental units did not 
Table I: Mean levels and standard errors (se) of TVC at $22^{\circ}$ and $36^{\circ} \mathrm{C}$ (CFU/mL) from water samples, prevalence of samples with microbial levels above the threshold levels established by Italian law (2I) (no samples exceeded the CDC 2003 threshold value).

\begin{tabular}{|c|c|c|c|c|c|c|}
\hline & \multicolumn{6}{|c|}{ Cup fillers } \\
\hline & \multicolumn{3}{|c|}{$22^{\circ} \mathrm{C}$} & \multicolumn{3}{|c|}{$36^{\circ} \mathrm{C}$} \\
\hline & $\mathrm{T}_{0}$ & $\mathrm{~T}_{1}$ & Statist. anal. & $\mathrm{T}_{0}$ & $\mathrm{~T}_{1}$ & Statist. anal. \\
\hline Logarithmic mean & $1.6(\mathrm{se}=0.15)$ & $1.3(\mathrm{se}=0.14)$ & $t=1.38(p=0.16)$ & $1.7(\mathrm{se}=0.15)$ & $1.2(\mathrm{se}=0.13)$ & $t=2.24(p=0.02)$ \\
\hline Geometric mean & 42.7 & 21.9 & & 47.9 & 17.4 & \\
\hline \multirow[t]{4}{*}{$\%$ positives (Italian law) } & $41.2(42 / 102)$ & $36.2(37 / 102)$ & $M c N=1.71(p=0.19)$ & $60.8(62 / 102)$ & $47.0(48 / 102)$ & $M c N=10.32(p=0.001)$ \\
\hline & \multicolumn{6}{|c|}{ Air-water syringes } \\
\hline & \multicolumn{3}{|c|}{$22^{\circ} \mathrm{C}$} & \multicolumn{3}{|c|}{$36^{\circ} \mathrm{C}$} \\
\hline & $\mathrm{T}_{0}$ & $\mathrm{~T}_{1}$ & Statist. anal. & $\mathrm{T}_{0}$ & $\mathrm{~T}_{1}$ & Statist. anal. \\
\hline Logarithmic mean & $1.8(\mathrm{se}=0.15)$ & $1.4(\mathrm{se}=0.14)$ & $t=2.11(p=0.03)$ & $1.7(\mathrm{se}=0.13)$ & $1.2(\mathrm{se}=0.13)$ & $t=2.55(p=0.01)$ \\
\hline Geometric mean & 64.6 & 23.4 & & 49.0 & 16.6 & \\
\hline \multirow[t]{4}{*}{$\%$ positives (Italian law) } & $48.9(47 / 96)$ & $31.6(30 / 95)$ & $\begin{array}{c}\mathrm{McN}=13.14(p= \\
0.0003)\end{array}$ & $63.5(61 / 96)$ & $46.3(44 / 95))$ & $\begin{array}{c}\mathrm{McN}=13.14(p= \\
0.0002)\end{array}$ \\
\hline & \multicolumn{2}{|c|}{ Tap water } & & & & \\
\hline & $22^{\circ} \mathrm{C}$ & $36^{\circ} \mathrm{C}$ & & & & \\
\hline & $\mathrm{T}_{0}$ & $\mathrm{~T}_{0}$ & & & & \\
\hline Logarithmic mean & $0.5(\mathrm{se}=0.07)$ & $0.7(\mathrm{se}=0.10)$ & & & & \\
\hline Geometric mean & 3.0 & 5.4 & & & & \\
\hline$\%$ positives (Italian law) & $4.4(4 / 91)$ & $29.3(27 / 91)$ & & & & \\
\hline
\end{tabular}

Statistical analysis of differences between $T_{0}$ and $T_{1}$ (t-test for paired samples for means and McNemar test for proportions)

change over time (Table 5), with no significant differences between $\mathrm{T}_{0}$ and $\mathrm{T}_{1}$.

\section{Discussion}

Some dental surgery environments in the eight cities involved in this study showed high levels of biocontamination. Water from oral rinsing cups and air-water syringes was already contaminated before work activity started, but the total microbial count never exceeded 500 $\mathrm{CFU} / \mathrm{mL}$ (CDC 2003 threshold). The percentage of positive samples significantly decreased during the day $(\mathrm{p}<$

Table 2: Prevalence of Legionella spp. and Pseudomonas aeruginosa in samples from dental unit waters

\begin{tabular}{lccc}
\hline \multicolumn{4}{c}{ Pseudomonas aeruginosa } \\
\hline Legionella spP & Negative n. (\%) & Positive n. (\%) & Total n. (\%) \\
\hline Negative & $47(54.0)$ & $11(12.7)$ & $58(66.7)$ \\
Positive & $28(32.2)$ & $1(1.1)$ & $29(33.3)$ \\
Total & $75(86.2)$ & $12(13.8)$ & $87(100.0)$ \\
\hline
\end{tabular}

One-tailed Fisher's exact test $\mathrm{p}=0.042$
$0.05)$, especially in air-water syringes. Some authors $[2,20]$ have suggested that this may be due to the presence of biofilms in DUWSs, as well as night-time stagnation, and in most cases, to the absence of adequate disinfection systems. Moreover, this seems to confirm that when water and air emission from syringes stops, a short depression sucks in external polluting particles [29].

Ineffective maintenance and disinfection of dental units probably causes $P$. aeruginosa colonization, as demonstrated by the percentage of positive water samples (13.8\%). Moreover, P. aeruginosa can hide the presence of Legionella spp. [29]. Thus, even if the total microbial count does not always represent a risk for patients and health care workers, the presence of an opportunistic pathogen like $P$. aeruginosa may be dangerous, especially when associated with others microorganisms with a predilection for water habitats (e.g., Legionella and Aeromonas spp.) [29].

The water contamination results obtained in this study provide a contribution to the wider European investigation [19], which did not include Italian data. TVC was 
Table 3: Mean levels of air contamination assessed by IMA (TVC at $36^{\circ} \mathrm{C}$, cfu/plate), prevalence of samples with microbial levels above the threshold level (25 CFU/plate)

\begin{tabular}{cccc}
\hline & $\mathrm{T}_{0}$ & $\mathrm{~T}_{\mathrm{I}}$ & Statistical analysis \\
\hline Logarithmic mean & $0.8(\mathrm{se}=0.1 \mathrm{I})$ & $1.4(\mathrm{se}=0.07)$ & $\mathrm{t}=4.48(\mathrm{p}<0.000 \mathrm{I})$ \\
Geometric mean & 6.5 & 23.4 & $\mathrm{McN}=12.07(\mathrm{p}=0.0005)$ \\
\% positives & $12.5(4 / 32)$ & $56.2(18 / 32)$ & \\
\hline
\end{tabular}

Table 4: Mean levels of air contamination assessed by SAS (TVC at $36^{\circ} \mathrm{C}, \mathrm{CFU} / \mathrm{m}^{3}$ ), prevalence of samples with microbial levels above the threshold level (180 CFU/m³)

\begin{tabular}{cccc}
\hline & $\mathrm{T}_{0}$ & $\mathrm{~T}_{\mathrm{I}}$ & Statistical analysis \\
\hline Logarithmic mean & $2.0(\mathrm{se}=0.05)$ & $2.0(\mathrm{se}=0.07)$ & $\mathrm{t}=0.11(\mathrm{p}=0.91)$ \\
Geometric mean & 104.7 & 107.2 & $\mathrm{McN}=0.75(\mathrm{p}=0.39)$ \\
\hline positives & $39.1(18 / 46)$ & $34.8(16 / 46)$ & \\
\hline
\end{tabular}

similar to the lowest reported counts, while the percentage of samples positive for Legionella spp. and P. aeruginosa was higher.

As to air microbial contamination, a high percentage of samples exceeded the limits of 25 and 180 for IMA and $\mathrm{CFU} / \mathrm{m}^{3}$, respectively, whereas their mean values were lower than the threshold. IMA values increased during work activity $(\mathrm{p}<0.0001)$, as expected, while CFU $/ \mathrm{m}^{3}$ values remained almost unchanged. Since an increase in air biological contamination caused by microbial dispersion from people and production of microbial aerosols is inevitable in dental practices, these results seem contradictory. A mutual relationship between the results obtained by active and passive sampling has been demonstrated in some studies [30-36]. Our study showed the need to promote further studies in this field.

As to surfaces, high microbial accumulation was registered at the beginning of work activities and increased during the day. More than $50 \%$ of samples showed values above the threshold. This was probably due to inadequate disinfection at the end of work activities and to the absence of proper aspiration systems, which caused a night-time fallout of airborne particles. On the other hand, the contam- ination level does not exclusively depend on the number of patients and health operators, but also on failure to use films, blotting papers or trays to protect work surfaces on which instruments are placed during treatment, and which represent an indicator of contamination by aerosols, while the push-button panel indicates contamination due to manipulation.

An exhaustive analysis of microorganisms in air and surfaces was not completed, because the aim of this study was to propose a monitoring method for obtaining quantitative data, such as indicators of environmental hygienic conditions, leaving aside for the moment, identification of specific pathogens and the study of particular situations such as epidemic events.

\section{Conclusion}

The control of indoor biological contamination is particularly important, as various pathogens may be transmitted from the environment to patients. Dental care is still a risk factor for several infections, especially in immunocompromised subjects [6]. Some authors [37] have insisted on the importance of individual protection systems and of frequent disinfection procedures in order to reduce the infection risk associated with dental aerosols,

Table 5: Mean levels of microbial accumulation (TVC at $36^{\circ} \mathrm{C}, \mathrm{cfu} / \mathrm{cm}^{2}$ ) of operative surfaces (countertops and swiches), prevalence of samples with levels above the threshold level $\left(1 \mathrm{cfu} / \mathrm{cm}^{2}\right)$

\begin{tabular}{|c|c|c|c|c|c|c|}
\hline & \multicolumn{3}{|c|}{ Countertops } & \multicolumn{3}{|c|}{ Switches } \\
\hline & $\mathrm{T}_{0}$ & $T_{1}$ & Stat. anal. & $\mathrm{T}_{0}$ & $T_{1}$ & Stat. anal. \\
\hline Logarithmic mean & $0.01(\mathrm{se}=0.08)$ & $0.12(\mathrm{se}=0.08)$ & $t=1.10(p=0.27)$ & $-0.15(\mathrm{se}=0.09)$ & $0.005(\mathrm{se}=0.09)$ & $t=1.23(p=0.22)$ \\
\hline Geometric mean & 1.0 & 1.3 & & 0.7 & 1.0 & \\
\hline$\%$ positives & $5 \mathrm{I} .4(57 / \mathrm{III})$ & $54.1(60 / 111)$ & $\mathrm{McN}=0.3 \mathrm{I}(\mathrm{p}=0.58)$ & $48.2(53 / 110)$ & $52.7(57 / 110)$ & $M c N=1.8(p=0.18)$ \\
\hline
\end{tabular}


although the efficacy of these products varies over time [37]. In any case, it seems vitally important to promote staff training programs on the correct use of control procedures in work environments [8].

\section{Competing interests}

The authors declare that they have no competing interests.

\section{Authors' contributions}

The authors contributed equally to this work, read and approved the final manuscript.

\section{Acknowledgements}

The present research was equally financed by the following Italian University:

Università degli Studi di Sassari, Sassari, Italy

Università degli Studi di Napoli "Parthenope", Napoli, Italy

Università degli Studi di Bari, Bari, Italy

Università degli Studi di Modena e Reggio Emilia, Modena, Italy

Università degli Studi di L'Aquila, L'Aquila, Italy

Università degli Studi di Perugia, Perugia, Italy

Università degli Studi "La Sapienza", Roma, Italy

SItl (Italian Society of Hygiene Preventive Medicine and Public Health) Working Group "Hygiene in Dentistry" participants:

Bari (De Benedittis M), Brescia (Alberti A, Ferretti D, Gigola P, Grottolo M, Zani C, Zerbini I), L'Aquila (Giannoni M, Giuliani AR, Trasarti S), Modena (Guerrieri E), Napoli (D'Onofrio V, Gallè F, Lucariello A), Perugia (Pasquino V, Savino A), Roma (Tarsitani G), Sassari (Campus G, Lugliè PF, Maida C, Sotgiu G).

\section{References}

I. Barbeau J, Nadeau C: Dental Unit waterline microbiology: a cautionary tale. J Can Dent Assoc 1997, 63( ( 0):775-9.

2. Checchi L, Montebugnoli L, Samaritani S: Contamination of the turbine air chamber: a risk of cross infections. J Clin Periodontol 1998, 25:607-II.

3. Singh T, Coogan MM: Isolation of pathogenic Legionella species and Legionella-laden amoebae in dental unit waterlines. J Hosp Infect 2005, 6 I:257-62.

4. Zanetti F, Stampi S, De Luca G, Fateh-Moghadam P, Antonietta M, Sabattini B, Checchi L: Water characteristics associated with occurrence of Legionella pneumophila in dental units. Eur J Oral Sci 2000, 108:22-8.

5. King TB, Muzzin KB, Berry CW, Anders LM: The effectiveness of an aerosol reduction device for ultrasonic scalers. J Periodontol 1997, 68:45-49.

6. Pankhurst $C L$, Coulter WA: Do contaminated dental unit waterlines pose a risk of infection? J Dentistry 2007, 35:7I 2-20.

7. Mills SE: The dental unit waterline controversy: defusing the myths, defining the solutions. J Am Dent Assoc 2000, | 31:|427-4I.

8. Centers For Disease Control And Prevention: Guidelines for Infection Control in Dental Health-Care Setting - 2003. MMWR 2003, 52(No RR-17): I-66.

9. Allsopp J, Basu MK, Browne RM, Burge PS, Matthews JB: Survey of the use of personal protective equipment and prevalence of work related symptoms among dental staff. Occup Environ Med 1997, 54:125-134.

10. Pankhrust CL: Risk assessment of dental unit waterline contamination. Prim Dent Care 2003, 10:5-10.

II. Araujo MW, Andreana S: Risk and prevention of transmission of infectious diseases in dentistry. Quintessence Int 2002, 33:376-82.

12. Hu T, Li G, Zuo Y, Zhou X: Risk of hepatitis B virus transmission via dental handpieces and evaluation of an anti-suction device for prevention of transmission. Infect Control Hosp Epidemiol 2007, 28:80-2.

13. Naidoo S: Hepatitis B: Implications for the oral health worker. SADJ 2003, 58: 196-7.

14. Thomas DL, Gruninger SE, Siew C, Joy ED, Quinn TC: Occupational risk of hepatitis $C$ infections among general dentists and oral surgeons in North American. Am J Med 1996, 100:4I-5.

15. Waddel C: Perception of HIV risk and reported compliance with universal precautions: a comparison of Australian dental hygienists and dentists. J Dent Hyg 1997, 71:17-21.

16. Napoli C, Tatò D, latta R, Montagna MT: Assessment of occupational risk of Legionella spp infection among dental healthcare personnel. Ig Sanità Pubbl 2007, 6:683-9.

17. ADA Statement On Dental Unit Waterlines: J Am Dent Assoc 1996, 127:185-6.

18. ADA: Dental unit water quality. 2007 [http://www.ada.org].

19. Walker JT, Bradshaw DJ, Finney M, Fulford MR, Frandsen E, ØStergaard E, Ten Cate JM, Moorer WR, Schel AJ, Mavridou A, Kamma JJ, Mandilara G, Stösser L, Kneist S, Araujo R, Contreras N, GoroncyBermes P, O'Mullane D, Burke F, Forde A, O'Sullivan M, Marsh PD: Microbiological evaluation of dental unit water systems in general dental practice in Europe. Eur J Oral Sci 2004, I I 2:412-8.

20. Monarca S, Grottolo M, Renzi D, Paganelli C, Sapelli P, Zerbini I, Nardi G: Evaluation of environmental bacterial contamination and procedures to control cross-infection in a sample of Italian dental surgeries. Occ Env Med 2000, 57:72I-6.

21. Prospero E, Savini S, Annino I: Microbial aerosol contamination of dental healthcare workers' faces and other surfaces in dental practice. Infect Control Hosp Epidemiol 2003, 24:139-4I.

22. Decreto Legislativo 2 febbraio 2001 , n. 3 I: "Attuazione della direttiva 98/83/CE relativa alla qualità delle acque destinate al consumo umano". Gazzetta Ufficiale n. 52 del 03-03-200 I suppl. ord. n. 41.

23. Council Directive $98 / 83 / \mathrm{EC}$ of 3 November 1998 on the quality of water intended for human consumption: Official Journal of the European Community L330 1998:32-54.

24. G.U. 5 maggio 2000 n. 103: Linee guida per la prevenzione e il controllo della legionellosi.

25. Pasquarella $C$, Pitzurra $O$, Savino $A$ : The index of microbial air contamination. J Hosp Infect 2000, 46:24I-56.

26. NHS Estates: Specialised ventilation for healthcare premises Part A: Design and validation. Health Technical Memorandum 03012007.

27. Pitzurra M, Savino A, Pasquarella C: Microbiological environmental monitoring. Ann lg 1997, 9:439-54.

28. Poletti $L$, Pasquarella $C$, Pitzurra M, Savino A: Comparative efficiency of nitrocellulose membranes versus RODAC plates in microbial sampling on surfaces. J Hosp Infect 1999, 4I: I95-20I.

29. Rowland BM: Bacterial contamination of dental unit waterlines: what is your dentist spraying into your mouth? Clin Microbiol 2003, 25:73-7.

30. European Commission: EC Guide to Good Manufacturing Practice. Revision to Annex I. Manufacture of Sterile Medicinal Products. Brussels, 30 May 2003.

31. Liguori G, Spagnoli G, Agozzino E, Marinelli A, Signoriello G, Lucariello A, Albano L, Di Onofrio V, Cammarota B, Capozza G, Lombardi $\mathrm{R}$, Marinelli $\mathrm{P}$ : Biological risk in the operating room: microbiological monitoring of the environment and analysis of the associated variables. Ann lg 2005, I 7:385-98.

32. Pasquarella C, Masia MD, Nnanga N, Sansebastiano GE, Savino A, Signorelli C, Veronesi L: Microbial air monitoring in operating theatre: active and passive samplings. Ann Ig 2004, 16:375-86.

33. Pitzurra M, Morlunghi P: Contaminazione microbica dell'aria atmosferica: correlazione tra due diverse metodiche di rilevazione. Ig Mod 1978, 3:489-50I. 
34. Orpianesi C, Cresci A, La Rosa F, Saltalamacchia G, Tarsi R: Evaluation of microbial contamination in a hospital environment. Comparison between the Surface Air System and the traditional method. Nuovi Ann Ig Microbiol I 983, 34:I7I-85.

35. Whyte W: Sterility assurance and models for assessing airborne bacterial contamination. J Parenter Sci Technol 1986, 40:188-97.

36. Perdelli F, Sartini M, Orlando M, Secchi V, Cristina ML: Relationship between settling microbial load and suspended microbial load in operating rooms. Ann Ig 2000, I 2:373-80.

37. Schel AJ, Marsh PD, Bradshaw DJ, Finney M, Fulford MR, Frandsen E, Østergaard E, ten Cate JM, Moorer WR, Mavridou A, Kamma JJ, Mandilara G, Stösser L, Kneist S, Araujo R, Contreras N, GoroncyBermes P, O'Mullane D, Burke F, O'Reilly P, Hourigan G, O'Sullivan $\mathrm{M}$, Holman R, Walker JT: Comparison of the efficacies of disinfectants to control microbial contamination in dental unit water systems in general dental practices across the European Union. Appl Environ Microbiol 2006, 72:1380-7.

\section{Pre-publication history}

The pre-publication history for this paper can be accessed here:

http://www.biomedcentral.com/1471-2458/8/187/pre

pub

Publish with Bio Med Central and every scientist can read your work free of charge

"BioMed Central will be the most significant development for disseminating the results of biomedical research in our lifetime."

Sir Paul Nurse, Cancer Research UK

Your research papers will be:

- available free of charge to the entire biomedical community

- peer reviewed and published immediately upon acceptance

- cited in PubMed and archived on PubMed Central

- yours - you keep the copyright

Submit your manuscript here:

http://www.biomedcentral.com/info/publishing_adv.asp 